\title{
Rolverwagting van Gebiedstoesighouers IN 'N AANTAL TRANSVAALSE PROVINSIALE HOSPITALE
}

\author{
S VAN TONDER \\ Departement Verpleegkunde, Unisa
}

\section{SUMMARY}

The area supervisor has an inviduous role to fulfil. She has part of the chief matron's responsibilities but not her authority. At the same time she functions as a person with specialised and extensive knowledge.

An in depth literature study has revealed that the area supervisor has eight roles namely that of leader, co-ordinator, clinical expert, supervisor, educator, human relations expert, and inspectress. Area supervisors fill different roles and each area supervisor has a preference for specific roles.

From research undertaken in the Transvaal these roles were placed in a priority sequence. The findings indicate that area supervisors have role expectations but that these role expectations are not satisfied.

\section{INLEIDING}

Die rol van die gebiedstoesighouer is 'n onbenydenswaardige een want die gebiedstoesighouer is ' $\mathrm{n}$ persoon wat 'n deel van die hoofmatrone se verantwoordelikhede het maar nie haar gesag nie. Sy funksioneer terselfdertyd as ' $n$ spesialis en as iemand met ' $\mathrm{n}$ breë kennis. Sy voldoen aan die botsende eise van haar seniors, haar ondergeskiktes en ander toesighouers terwyl die werk nietemin gedoen moet word. Weens die botsende en veranderende eise wat aan die toesighouer gestel word, is dit dikwels vir haar moeilik om 'n konstante gedragspatroon te ontwikkel of konstante funksies uit te voer (Uyterhoeven: 76).

Sommige organisasies sien die pos van die gebiedstoesighouer slegs as tydelik en as voorbereiding en ondervinding vir verantwoordelikhede op uitvoerende vlak. In werklikheid is hierdie pos egter belangrik vir die organisasie want dit is die beslissende vlak vir die implementering van die organisasie se doelwitte (Dressler: 358 ).

Die gebiedstoesighouers is afhanklik van die gedragsondersteuning van beide die hoof-/eerste matrone en die verpleegkundiges. Beide kategorieë heg verskillende verwagtings aan die rol van die gebiedstoesighouer. Die gebiedstoesighouer identifiseer haarself met

Hierdie artikel is gebaseer op 'n verhandeling ingehandig vir die graad MA(Cur) by Unisa. die gegriefdheid van die verpleegkundiges in haar area teenoor die hospitaal se organisatoriese gesagstruktuur en professionele eise van haar beroep, en as administrateur vereenselwig sy haarself met die hoof-/eerste matrone wat van haar verwag om gesag uit te oefen (Dressler: 359).

\section{ROLSIENING}

In die literatuur oor verpleegtoesighouding verwys talle skrywers na die verskeie rolle van die verpleegtoesighouer.

In Phoenecia verwys Searle ook na talle rolle. Ten eerste verwys sy na die rol van toesighouer wat saalinspeksies doen en die eise wat dié rol aan die gebiedstoesighouers stel (Searle (1961): 2). Tweedens wys Searle op die toesighouer se leierskapsrol waar sy die gebiedstoesighouer sien as die leier in die hospitaal wat die naaste is aan diegene wat die verpleegsorg voorsien en diegene wat die verpleegsorg ontvang (Searle (1961): 7). Ten derde verwys Searle na die rol van die gebiedstoesighouer as opvoedkundige (Searle (1961): 46-49). In 'n latere publikasie van Searle verwys sy na die gebiedstoesighouer se rol as kliniese deskundige en vindingryke persoon (Searle (1982): 41).

Watkinson onderskei drie rolle van die verpleegtoesighouer en wel in die volgende volgorde: leier, kennisbron en handhawer van goeie menseverhoudings (Watkinson: $1046)$
Aan die anderkant gee Carr die rolle van die verpleegtoesighouer in die volgende volgorde aan: toesighouer, opvoeder en handhawer van menseverhoudings (Carr: 89).

Manez plaas weer klem op die verpleegtoesighouer se koördineringsrol (Manez: 65).

White het navorsing gedoen oor die persepsie van leierskapstyle deur verpleegkundiges in leierskapsposisies. Sy plaas heelwat klem op die leiersrol van die verpleegtoesighouer (White: 44).

Falls verwys na die deskundigheid van die gebiedstoesighouer (Falls: 15).

Die gebiedstoesighouers vervul verskillende rolle en elkeen het "n voorkeur vir spesifieke rolle

\section{ROLVERWAGTINGS VAN GEBIEDSTOESIGHOUERS}

Met onlangse navorsing wat in Transvaal gedoen is oor die rol en funksies van gebiedstoesighouers in hospitale is 'n lys van agt rolle aan gebiedstoesighouers gegee om in prioriteitsvolgorde te plaas volgens hul siening van die rol van die gebiedstoesighouer

Aan die hand van 'n omvattende literatuurstudie is agt rolle geidentifiseer, naamlik die rolle van leier. koördineerder, vindingryke persoon, kliniese deskundige, toesighouer, opvoeder, deskundige in menseverhoudings en inspektrise.

Om die prioriteitsvolgorde te bepaal is die Likert-tipe skaal aangepas om 'n rekeningkundige gemiddelde te verkry. Die prioriteitsvolgorde wat bepaal is, is soos volg. 


\section{Eerste - Leier}

By uitstek het die gebiedstoesighouers hul rol as dié van 'n leier gesien. Hul wil graag die leier wees van die verpleegspan en hul leidinggewende funksies het 'n hoë positiewe respons getoon, maar ander aspekte het aangedui dat hul geïsoleerd is en buite die verpleegsorgspan staan. Die navorsing het getoon dat gebiedstoesighouers hulself nie as die leiers van die verpleegsorgspanne sien nie.

\section{Tweede - Deskundige in}

\section{menseverhoudings}

Die plasing van die rol is volgens die bevindings van die ondersoek geregverdig. Gebiedstoesighouers gee hoë prioriteit aan die handhawing van menseverhoudings en sien dit as 'n belangrike aspek van hul funksies. Die navorsing het egter getoon dat byna die helfte van die gebiedstoesighouers wat by die ondersoek betrek was oor min of redelike vermoëns beskik om goeie menseverhoudings te handhaaf of oor hul menseverhoudings onseker is. Die gebrek aan vermoëns om die funksie te verrig moet die gebiedstoesighouer frustreer. Hierdie bevinding is ' $n$ aanduiding dat indiensopleiding oor menseverhoudings onontbeerlik is.

\section{Derde - Koördineerder}

In hierdie verband verwys Falls na die besondere vermoë waaroor die verpleegtoesighouer moet beskik om verskeie dissiplines in die gesondheidspan te konsulteer en om hul aktiwiteite te koördineer met die oog op beter pasiëntsorg (Falls: 15). Die navorsing het egter 'n gebrekkige koördineringsbesef by gebiedstoesighouers aangedui wat saamval met 'n gebrek aan kontak en kommunikasie met ander dissiplines in die gesondheidspan. Alhoewel die ondersoek aangedui het dat die gebiedstoesighouer se koördineringsfunksies nie na wense is nie, kan die plasing van koördineerder as bewys verklaar word.

\section{Vierde - Opvoeder}

Die onderrigverantwoordelikhede van die gebiedstoesighouer sluit haar verantwoordelikhede ten opsigte van indiensopleiding, oriëntering, kliniese onderrig en formele onderrig aan na-registrasiestudente in.
Die ondersoek wat gedoen is het getoon dat gebiedstoesighouers toesien dat die saalsusters hul verantwoordelikhede ten opsigte van onderrig nakom en dat daar goeie samewerking tussen saalsusters en kliniese dosente bestaan. Dit het egter ook getoon dat gebiedstoesighouers nie by beplanning van opleidingsprogramme betrokke is of die saalsusters help en ondersteun in die uitvoering van hierdie funksies nie.

Die bevindings kan moontlik toegeskryf word aan 'n gebrek aan kennis by gebiedstoesighouers. Daar moet egter in gedagte gehou word dat die meerderheid gebiedstoesighouers oor sale van verskillende dissiplines/dienste toesig hou. In die lig hiervan kan daar nie van haar verwag word om 'n deskundige ten opsigte van al die dissiplines/ dienste te wees nie. Dit kan moontlik die rede wees waarom so 'n groot persentasie gebiedstoesighouers nie by indiensopleiding en kliniese onderrig betrokke is nie.

Daar is nie genoeg bewyse in die ondersoek gevind wat dié plasing regverdig nie.

\section{Vyfde - Toesighouer}

Die toesighoudende funksies van die gebiedstoesighouer is gebaseer op die kontroleringsfunksies, saalrondtes en addisionele rondtes wat sy moet doen om pasiënte te besoek en op die kontrolering of inspeksie van elke aspek van die aktiwiteite in haar area van toesig.

Die bevindings van die ondersoek toon 'n sterk toesighoudingstendens aan die kant van die gebiedstoesighouers. Tog sien die gebiedstoesighouers hul rol nie as dié van toesighouer nie. Die plasing van die rol van toesighouer kan nie uit die ondersoek gestaaf word nie.

\section{Sesde - Vindingryke persoon}

\section{Sewende - Kliniese deskundige}

Die plasing van vindingryke persoon, sesde en kliniese deskundige. sewende stem ooreen met die bevindings van die ondersoek.

'n Groot hoeveelheid gebiedstoesighouers in Transvaal toon in gebrek aan 'n sekere peil van kennis en insig in die uitvoering van hul rol en funksies as 'n hoofverpleegkundige. Die bevinding spruit voort uit die feit dat gebiedstoesighouers nie in besit is van 'n na-registrasiekwalifikasie wat op hul toesiggebied toepaslik is nie. Daar is min getuienis wat bevestig dat na-registrasiekwalifikasies bepalend is vir die gebiedstoesighouer se toesiggebied. Genoemde stelling kan ook toegeskryf word aan die feit dat die meerderheid gebiedstoesighouers oor sale/eenhede van verskillende spesialiteite of dienste toesig hou.

Bevindings van die ondersoek het ook aangedui dat gebiedstoesighouers hul na-registrasiekwalifikasies sien as nie-toepaslik op hul toesiggebied. Dit kom daarop neer dat die gebiedstoesighouers nie hul breër teoretiese kennis in die praktyk kan toepas nie en dit moet noodwendig tot frustrasie lei.

\section{Agste - Inspektrise}

Die plasing van die rol kan nie uit die ondersoek gestaaf word nie. Die nagaan van voorrade in die afdelings, afskryf en vervanging van toerusting, van bestellings vir voorrade, van verslae wat deur die verpleegpersoneel opgestel word en die kontrolering van diensroosters en verskeie boeke in die sale/eenhede onder haar toesig is 'n funksie van die gebiedstoesighouer. Sy moet gereelde rondtes/inspeksies in haar area onderneem en alle items nagaan wat sy veronderstel is om te kontroleer (Searle (1982): 40-41).

Die plasing van die rol dui daarop dat die gebiedstoesighouers hulself nie graag in die rol van inspektrise sien nie. Tog het die ondersoek getoon dat sy 'n sterk kontroleringsfunksie verrig.

\section{GEVOLGTREKKING}

Die gevolgtrekking wat gemaak kan word uit die bespreking van die rolverwagting van die gebiedstoesighouer is dat die werklikheid in verband met toesighouding, nie met die rolverwagtings van die gebiedstoesighouers ooreenstem nie. Die funksies wat aan die gebiedstoesighouers opgedra word, voldoen nie aan haar rolverwagting nie. As daar nie aan die rolverwagting voldoen word nie kan daar ook geen werksbevrediging wees nie.

Vervolg op bl. 56 